\title{
Nilai Gizi dan Daya Terima Cookies Ikan Gabus Sebagai Makanan Tambahan Untuk Ibu Hamil di Kabupaten Sleman, DIY
}

\author{
Eugenius Phyowai Ganap로 Pakartian Ayu Sugmana², Riantina Rizky Amalia ${ }^{3}$, Laksmi Ika Hidayati ${ }^{4}$ \\ 1,2,3,4 Departemen Obstetri dan Ginekologi, Fakultas Kedokteran, Kesehatan Masyarakat dan Keperawatan, \\ Universitas Gadjah Mada, Yogyakarta, Indonesia \\ Korespondensi: phyowai_ku@yahoo.com; riantina.amalia@gmail.com
}

Submisi: 1 November 2020; Revisi: 28 Desember 2020; Penerimaan: 13 Januari 2021

\begin{abstract}
Background: Pregnant women needs more nutritional intake during pregnancy. Lack of nutritional intake during pregnancy may leads to malnutrition problems. Therefore, it is necessary to provide supplemetary food (PMT) for pregnant women to meet the nutritional needs during pregnancy.

Objective: To find the best formulation of snakehead fish cookies that are well accepted by pregnant women and to test their nutritional content and microbiological contamination.

Method: This study is an analytical survey study begins with the formulation of snakehead fish cookies. The formulation of snakehead fish cookies is made by substituting wheat flour with snakehead fish flour by $50 \%$ and $60 \%$. The acceptance test was carried out on pregnant women in the Sleman District, DIY. Cookies with the best acceptability are then laboratory tested to see their nutritional content and microbiological contamination.

Results adn Discussion: The average value of all the organoleptic parameters of the cookies ranged from 3.41 to 3.91 on a scale of 5 . There was no significant difference onorganoleptic parameters between the formula $50 \%$ and $60 \%(\mathrm{p}<0.05)$. The snakehead fish cookies have the following nutritional content per $100 \mathrm{~g}$ of cookies: $565.9 \mathrm{kcal}$ energy, $14.09 \mathrm{~g}$ protein, $24.33 \mathrm{~g}$ fat, $72.62 \mathrm{~g}$ carbohydrates, and $2.68 \%$ water content. The nutritional content and microbiological contamination of snakehead fish cookies have met the quality requirements of supplementary food for pregnant by the Ministry of Health of the Republic of Indonesia.
\end{abstract}

Conclusion: Snakehead fish cookies are quite well accepted by pregnant women. Snakehead fish cookies can be used as an alternative supplementary foor for pregnant women.

Keywords: Snakehead fish cookies; complementary food for pregnant women; food acceptability

\section{ABSTRAK}

Latar Belakang: Ibu hamil mengalami peningkatan kebutuhan gizi selama kehamilan. Asupan gizi ibu hamil yang tidak tercukupi dengan baik akan menyebabkan masalah kekurangan gizi pada ibu hamil. Oleh karena itu, dibutuhkan pemberian makanan tambahan (PMT) bagi ibu hamil untuk membantu memenuhi kebutuhan gizi selama kehamilan.

Tujuan: Untuk mendapatkan formulasi cookies ikan gabus yang dapat diterima dengan baik oleh ibu hamil dan menguji kandungan gizi serta cemaran mikrobiologinya.

Metode: Penelitian ini merupakan penelitian survei analitik yang diawali dengan formulasi cookies ikan gabus. Formulasi cookies ikan gabus dilakukan dengan menyubstitusi tepung terigu dengan tepung ikan gabus sebesar $50 \%$ dan $60 \%$. Uji daya terima (warna, aroma, rasa, tekstur dan keselurhan) terhadap kedua formula cookies dilakukan kepada ibu hamil di wilayah Kabupaten Sleman, DIY. Cookies dengan daya terima terbaik kemudian diuji laboratorium untuk melihat kandungan gizi dan cemaran mikrobiologinya.

Hasil dan Pembahasan: Nilai rata-rata semua parameter organoleptik cookies berkisar antara 3,41-3,91 dari skala 5. Tidak terdapat perbedaan yang signifikan antara organoleptik cookies Formula $50 \%$ dan $60 \%(p<0,05)$. Cookies ikan gabus memiliki kandungan gizi per $100 \mathrm{~g}$ cookies sebagai berikut: energi 565,9 kcal, 14,09 g protein, 24,33 g lemak, 72,62 g karbohidrat, dan kadar air 2,68 \%. Kandungan gizi dan cemaran mikrobiologi dalam cookies ikan gabus telah memenuhi persyaratan mutu sebagai makanan tambahan ibu hamil sesuai dengan persyaratan mutu PMT ibu hamil oleh Kementerian Kesehatan Republik Indonesia.

Kesimpulan: Cookies ikan gabus dapat diterima dengan cukup baik oleh ibu hamil. Cookies ikan gabus telah memenuhi persyaratan mutu PMT ibu hamil dan dapat digunakan sebagai alternatif makanan tambahan untuk ibu hamil.

Kata Kunci: Cookies Ikan Gabus; PMT ibu hamil; daya terima 


\section{PENDAHULUAN}

Selama proses kehamilan, ibu hamil memerlukan asupan makanan yang sehat yang meliputi asupan energi, protein, vitamin, dan mineral yang cukup untuk memenuhi kebutuhan ibu hamil itu sendiri dan juga janin dalam kandungannya. Meski demikian, asupan makanan yang cukup bagi ibu hamil seringkali tidak terpenuhi dengan baik, terutama pada negara dengan penghasilaan rendah dan menengah, sehingga menimbulkan berbagai masalah kekurangan nutrisi. Pada negara miskin, prevalensi kurang gizi pada ibu hamil cukup tinggi dan menyebabkan keluaran perinatal yang buruk. ${ }^{1}$

Menurut Angka Kecukupan Gizi (AKG 2019) yang tercantum dalam Permenkes Nomor 28 Tahun 2019, ibu hamil memerlukan penambahan kalori sebesar $180 \mathrm{kcal} / \mathrm{hari}$ selama trimester 1 dan 300kcal/ hari selama trimester 2 dan 3 . Untuk kebutuhan protein, AKG 2019 menyebutkan penambahan protein sebanyak $20 \mathrm{~g} /$ hari baik untuk trimester 1 , trimester2, maupun trimester 3.

Nutrisi yang tidak tercukupi selama kehamilan dan juga munculnya infeksi merupakan penyebab dari mortalitas dan morbiditas maternal dan bayi, BBLR, dan IUGR. ${ }^{2}$ Hasil penelitian sebelumnya menyatakan bahwa bayi BBLR lebih banyak dilahirkan dari ibu hamil yang kekurang asupan gizi dibandingkan dengan ibu yang tercukupi gizinya dengan baik. ${ }^{3}$ Berdasarkan data Riskesdas 2013, prevalensi ibu hamil di Indonesia yang mengalami KEK adalah sebesar 24,2\%, dan prevalensi bayi BBLR di Indonesia sebesar 10,2\%. ${ }^{4}$ Bayi BBLR akan mempunyai risiko kematian, gizi kurang gangguan pertumbuhan, dan gangguan perkembangan anak. Bayi BBLR lebih rentan terhadap kemungkinan hambatan pertumbuhan, perubahan proporsi tubuh serta sejumlah perubahan metabolik dan kardiovascular. Selain itu, bayi BBLR juga akan juga akan memiliki risiko mortalitas dan morbiditas yang lebih tinggi, masalah kurang gizi, pendek atau kurus selama masa anak-anak. ${ }^{5}$ Oleh karena itu, pemerintah Indonesia mencanangkan program Gerakan Nasional Percepatan Perbaikan Gizi dalam 1.000 hari pertama kehidupan (1.000 HPK) yang tertuang dalam Peraturan Presiden Nomor 42 Tahun 2013, dengan sasaran ibu hami, ibu menyusui, dan anak usia di bawah 2 tahun. Salah satu cara mencegah defisiensi gizi dan meningkatkan status gizi ibu hamil adalah dengan melaksanakan program Pemberian Makanan Tambahan (PMT) untuk ibu hamil. ${ }^{6}$

Suplementasi makanan berpotein tinggi pada wanita hamil merupakan salah satu upaya untuk mencegah semakin tingginya angka BBLR. Ikan gabus (Channa striata) merupakan salah satu jenis ikan yang mempunyai kandungan protein yang cukup tinggi. Menurut penelitian beberapa ahli, ternyata kandungan protein ikan gabus lebih besar daripada jenis ikan konsumsi lainnya, seperti lele, nila, bandeng, ikan mas, dan lain-lain. ${ }^{7}$ Kadar protein yang dimiliki ikan gabus dapat dihitung dari setiap gram bagian yang dapat dimakan (BDD) ikan tersebut. Menurut Tabel Komposisi Pangan Indonesia, ikan gabus segar memiliki kandungan protein 16,2\% dan ikan gabus kering memiliki kandungan protein sebesar $58,0 \%^{8}$, sedangkan daging ikan gabus yang telah dikeringkan dan ditepungkan memiliki kandungan protein sekitar $66 \% .^{9}$ Menurut data Statistik Perikanan Tangkap Indonesia 2010, produksi ikan gabus di Provinsi DIY adalah sebesar 91 ton pada tahun 2010..$^{10}$ Cookies ikan gabus diketahui dapat digunakan sebagai makanan tambahan untuk ibu hamil. ${ }^{11}$ Berdasarkan latar belakang penelitian sebelumnya peneliti mencoba mengembangkan potensi ikan gabus, melalui formulasi dan uji daya terima cookies ikan gabus kepada ibu hamil untuk mendapatkan cookies ikan gabus yang memenuhi persyaratan mutu PMT ibu hamil dan dapat diterima dengan baik oleh ibu hamil.

\section{METODE}

Penelitian ini merupakan penelitian survei analitik yang didahului dengan melakukan proses formulasi cookies ikan gabus dengan menggunakan persentase substitusi tepung ikan gabus yang berbeda ( $50 \%$ dan $60 \%$ ). Cookies ikan gabus yang telah diformulasi tersebut kemudian diujikan sensoris kepada ibu hamil di wilayah Kabupaten Sleman, Provinsi DIY untuk dilihat daya terima ibu hamil sehingga didapatkan formulasi cookies ikan gabus yang terbaik yang dapat diterima oleh ibu hamil.

Populasi pada penelitian ini adalah ibu hamil di wilayah Provinsi DIY, sedangkan sampel pada penelitian ini adalah ibu hamil di wilayah Kabupaten Sleman. Pemilihan kriteria inklusi yaitu ibu hamil 
usia produktif. Sedangkan kriteria eksklusi yaitu memiliki alergi ikan, telur, dan coklat. Besar sampel pada penelitian ini ditetapkan sebanyak 70 orang, sesuai dengan acuan minimum besar sampel untuk uji hedonik yaitu 30 orang panelis per produk. ${ }^{12}$ Cara pemilihan sampel diambil dengan menggunakan teknik pengambilan sampel purposive sampling.

Data yang diambil dalam penelitian ini berupa data primer yang terdiri data hasil uji laboratorium produk meliputi kandungan gizi dan cemaran mikrobiologi cookies ikan gabus, serta data hasil uji sensoris oleh panelis tidak terlatih untuk melihat daya terima ibu hamil terhadap cookies ikan gabus.

Penelitian diawali dengan proses formulasi cookies ikan gabus. Sebelum formulasi dilakukan, terlebih dahulu disiapkan tepung ikan gabus yang dibuat dari fillet ikan gabus. Proses pembuatan tepung ikan gabus ditampilkan pada Gambar 1. Bahan-bahan yang digunakan dalam formulasi cookies ikan gabus terdiri dari tepung ikan gabus (substitusi $50 \%$ dan $60 \%$ dari tepung terigu), tepung terigu, gula aren, gula halus, margarin, butter, telur, kulit lemon, susu skim bubuk, bubuk kakao, maizena, dan baking powder (Tabel 1). Formulasi cookies ikan gabus dilakukan di Laboratorium Inkubator Fakultas Teknologi Pertanian, Universitas Gadjah Mada, Yogyakarta. Alur proses pembuatan cookies disajikan pada Gambar 2.

Tabel 1. Formulasi Komposisi Bahan Cookies Ikan Gabus

\begin{tabular}{lcc}
\multicolumn{1}{c}{ Bahan (\%) } & Formula $\mathbf{5 0 \%}$ & Formula $\mathbf{6 0 \%}$ \\
Tepung ikan gabus & 14,2 & 17,0 \\
Tepung terigu & 14,2 & 11,3 \\
Margarin & 10,6 & 10,6 \\
Butter & 14,2 & 14,2 \\
Gula aren & 21,3 & 21,3 \\
Gula halus & 14,2 & 14,2 \\
Telur & 1,4 & 1,4 \\
Lemon & 1,4 & 1,4 \\
Susu skim & 7,1 & 7,1 \\
Maizena & 1,1 & 1,1 \\
Baking powder & 0,3 & 0,3 \\
\hline \multicolumn{1}{c}{ Total (\%) } & 100,0 & 100,0 \\
\hline
\end{tabular}

Setelah formulasi selesai, dilakukan uji daya terima kepada para panelis tidak terlatih sejumlah
70 orang untuk mendapatkan formulasi cookies yang terbaik dan paling dapat diterima. Pengambilan panelis dilakukan di puskesmas-puskesmas dan rumah sakit yang terletak di wilayah Kabupaten Sleman, Provinsi DIY. Uji daya terima dilakukan dalam bentuk uji sensoris dengan menggunakan skala likert 5 tingkat untuk menilai organoleptik dari cookies ikan gabus dengan skor sebagai berikut:

- $\quad$ Skala 1 = Sangat tidak suka

- $\quad$ Skala 2 = Tidak suka

- $\quad$ Skala 3 = Sedikit suka

- $\quad$ Skala $4=$ Suka

- $\quad$ Skala 5 = Sangat suka

Sifat organoleptik cookies ikan gabus yang diuji oleh panelis terdiri atas warna, rasa, aroma, tekstur, dan keseluruhan. Setelah didapatkan formula cookies terbaik berdasarkan hasil uji sensoris oleh penelis, dilakukan uji proksimat, kadar Aw, kalori, dan cemaran mikrobiologis di Laboratorium Pusat Antar Universitas UGM. Uji mikrobiologi yang dilakukan meliputi uji E.coli, Staphylococcus aureus, Salmonella dan Total Plate Count untuk bakteri, yeast, dan jamur.

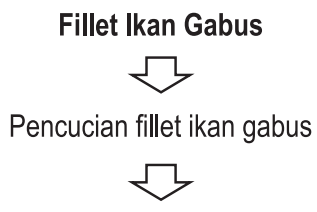

Penambahan perasan air lemon pada fillet ikan gabus untuk menghilangkan bau amis (diamkan selama 30 menit)

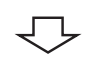

Perebusan fillet ikan gabus dalam air mendidih selama 10 menit

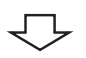

Penirisan fillet ikan gabus yang telah direbus

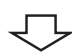

Penghancuran fillet ikan gabus menjadi bentuk yang lebih kecil

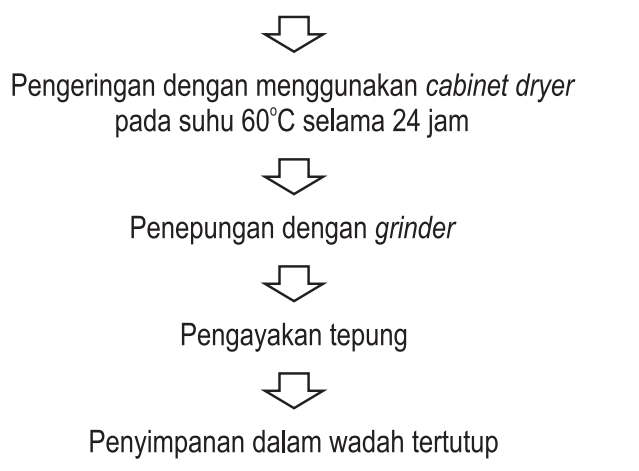

Gambar 1. Alur pembuatan tepung ikan gabus 
Sebelum penelitian ini dimulai, peneliti terlebih dahulu mengajukan ijin penelitian ke Badan Kesatuan Bangsa dan Politik, Pemerintah Kabupaten Sleman untuk dapat mengambil data ibu hamil dari Puskesmas-Puskesmas dan rumah sakit di wilayah Kabupaten Sleman, Provinsi DIY. Peneliti juga telah mengajukan ethical clearance kepada komisi etik Fakultas Kedokteran, Kesehatan Masyarakat, dan Keperawatan UGM, dengan Ref. No. KE/FK/0410/ $E C / 2019$. Ketika akan melakukan pengambilan data di lapangan, peneliti telah memberikan informed consent kepada subjek penelitian sebagai persetujuan untuk mengikuti penelitian. Data yang didapatkan dari subjek akan dijaga kerahasiaannya. Data yang diperoleh nantinya hanya akan digunakan untuk kepentingan ilmiah. Data diolah dan dianalisis dengan menggunakan perangkat lunak SPSS. Analisis data daya terima dilakukan menggunakan uji independent sample t-test.

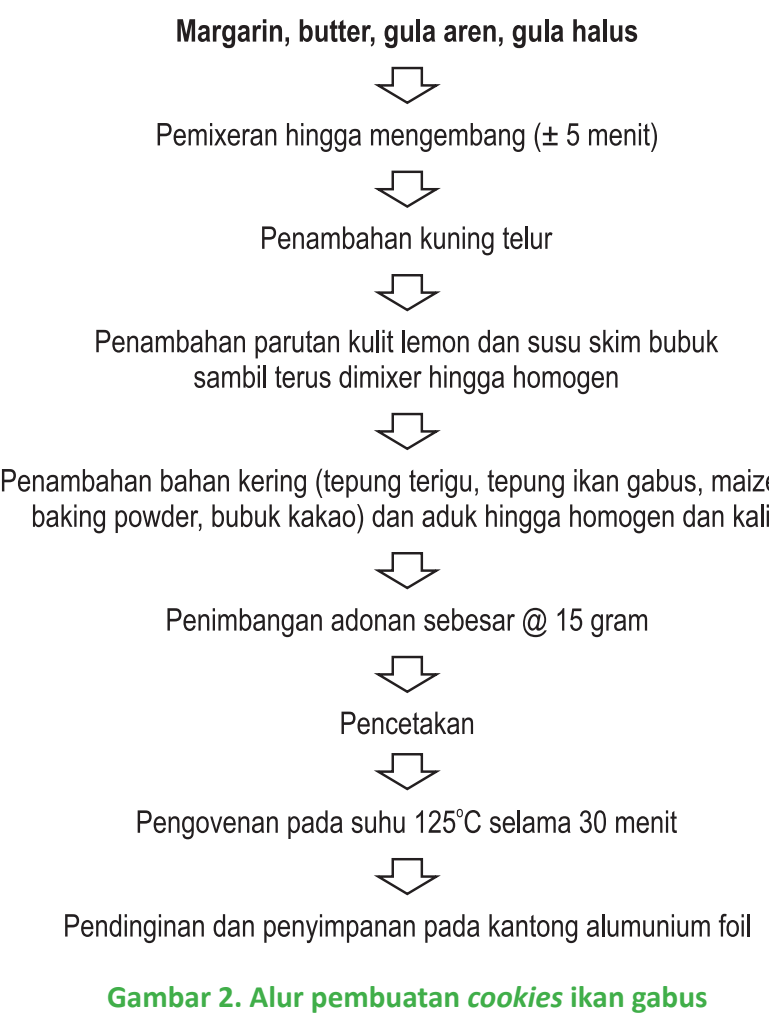

\section{HASIL DAN PEMBAHASAN}

\section{Daya Terima Cookies Ikan Gabus}

Cookies Ikan Gabus yang digunakan dalam penelitian, sebelumnya melalui pengujian daya terima dengan menggunakan 70 panelis ibu hamil yang tidak terlatih. Pengujian dilakukan dengan metode hedonik, ${ }^{12}$ untuk melihat tingkat kesukaan ibu hamil terhadap beberapa produk yang sejenis, yang dibedakan dengan presentase pemberian tepung ikan gabus, yaitu cookies ikan gabus dengan substitusi tepung ikan gabus sebesar $50 \%$ dan cookies ikan gabus dengan substitusi tepung ikan gabus sebesar $60 \%$. Nilai rata-rata parameter organoleptik (rasa, aroma, tekstur, warna, dan keseluruhan) berkisar antara 3,41-3,91 dari skala 5. Hal ini menunjukkan bahwa cookies ikan gabus dapat diterima dengan cukup baik oleh ibu hamil. Berikut hasil pengujian uji sensoris ditunjukkan pada Tabel 2.

Tabel 2. Hasil Uji Sensoris Formulasi Cookies Ikan Gabus ${ }^{\mathrm{a}}$

\begin{tabular}{lccc}
\multirow{2}{*}{ Variabel } & Formula 50\% & Formula 60\% & Mean (SD) \\
\cline { 2 - 3 } & \multicolumn{2}{c}{$p$} \\
Rasa & $3,46(0,94)$ & $3,47(1,09)$ & 0,993 \\
Aroma & $3,43(0,95)$ & $3,41(1,00)$ & 0,930 \\
Tekstur & $3,68(0,74)$ & $3,66(0,86)$ & 0,915 \\
Warna & $3,81(0,78)$ & $3,91(0,73)$ & 0,427 \\
Keseluruhan & $3,60(0,83)$ & $3,63(1,02)$ & 0,854 \\
\hline
\end{tabular}

${ }^{a}$ Dianalisis menggunakan independent sample t test

\section{Rasa}

Dalam penelitian ini cookies dibedakan dalam dua formulasi, yaitu dengan penambahan tepung ikan gabus $50 \%$ dan dengan penambahan tepung ikan gabus sebesar $60 \%$. Adanya penambahan bahan tertentu dapat mengakibatkan perbedaan rasa terhadap sebuah produk. ${ }^{13}$ Dalam penelitian ini, perbedaan substitusi jumlah tepung ikan gabus yang diberikan tidak menunjukkan beda yang signifikan $(p>0,05)$. Beberapa subjek melaporkan bahwa masih terdapat rasa amis pada cookies ikan gabus, baik pada formula $50 \%$ maupun $60 \%$. Rasa amis pada cookies ikan gabus telah diupayakan untuk diminimalkan dengan cara penambahan air perasan lemon pada proses pembuatan tepung ikan gabus serta dengan penambahan parutan kulit lemon pada saat proses pembuatan cookies.

\section{Aroma}

Aroma merupakan komponen penting dalam sebuah produk. $^{14}$ Aroma kerap kali dikaitkan dengan indera penciuman, Aroma biasanya 
diperoleh apabila terdapat uap dan komponen pembau yang mengenai silia sel olfatori hidung. ${ }^{15}$ Pada cookies ikan gabus, tidak terdapat perbedaan aroma yang signifikan dari kedua formula, baik formula $50 \%$ maupun formula $60 \%(p>0,05)$. Seperti pada rasa amis, aroma amis dari ikan gabus jg diminimalkan melalui proses penambahan air jeruk lemon saat pembuatan tepung ikan gabus, dan juga melalui penambahan kulit lemon pada proses pembuatan cookies. Hal ini sejalan dengan hasil penelitian yang dilaporkan oleh Puspitarini et al. bahwa bau amis pada ikan dapat dihilangkan dengan menambahkan kulit jeruk nipis dapat minyak yang digunakan untuk menggoreng, sehingga dihasilkan ikan goreng yang tidak berbau amis. ${ }^{16}$

\section{Tekstur}

Cookies merupakan biskuit yang terbuat dari adonan lunak dengan kadar lemak tinggi, yang memiliki tekstur kurang padat. ${ }^{17}$ Tekstur cookies ikan gabus dengan formula $50 \%$ dan $60 \%$ tidak memiliki perbedaan yang signifikan $(p>0,05)$. Kedua formula cookies sama-sama memiliki tekstur yang renyah. Hasil ini sejalan dengan penelitian-penelitian sebelumnya yang menyebutkan bahwa perbedaan formulasi kadar tepung ikan tidak berpengaruh signifikan pada daya terima subjek terhadap tekstur biskuit. ${ }^{18,19}$ Hasil berbeda ditunjukkan oleh penelitian lain yang menunjukkan perbedaan daya terima subjek terhadap tekstur biskuit pada formulasi kadar tepung ikan yang berbeda. ${ }^{20-21}$

\section{Warna}

Warna merupakan komponen pertama yang dipertimbangkan dalam memberikan sebuah penilaian terhadap produk makanan. ${ }^{22}$ Tidak terdapat perbedaan signifikan yang ditunjukkan dalam formula cookies ikan gabus $50 \%$ dan $60 \%$ $(p<0,05)$. Warna yang dihasilkan oleh cookies dengan penambahan kandungan ikan gabus lebih tinggi cenderung lebih gelap. Hasil yang sama juga ditunjukkan oleh Fitri \& Purwani, bahwa semakin banyak kadar tepung ikan yang ditambahkan dalam formulasi biskuit maka warna biskuit akan semakin gelap. ${ }^{21}$ Tepung ikan yang ditambahkan pada biskuit akan menyebabkan warna biskuit menjadi lebih gelap karena menimbulkan reaksi maillard, yaitu reaksi pencoklatan non-enzimatis yang terjadi karena adanya reaksi antara gula pereduksi dengan gugus amin bebas dari asam amino yang terkandung di dalam tepung ikan. ${ }^{23}$

\section{Keseluruhan}

Secara keseluruhan, tidak terdapat perbedaan nyata, baik dari formula cookies ikan gabus $50 \%$ maupun formula cookies ikan gabus $60 \%$, sehingga dalam penelitian ini, cookies yang dipilih untuk uji lanjutan (uji kandungan gizi dan cemaran mikrobiologi) adalah cookies dengan formula $60 \%$, yang diasumsikan memiliki kandungan protein lebih tinggi.

\section{Kandungan Gizi Cookies Ikan Gabus}

\section{Tabel 3. Perbandingan Kandungan Zat Gizi Cookies Ikan Gabus}

\begin{tabular}{|c|c|c|}
\hline \multirow[t]{2}{*}{ Zat Gizi } & $\begin{array}{c}\text { Syarat mutu biskuit } \\
\text { PMT Ibu Hamil }\end{array}$ & $\begin{array}{c}\text { Cookies Ikan } \\
\text { Gabus }\end{array}$ \\
\hline & $(\text { per } 100 \mathrm{~g})^{\mathrm{a}}$ & (per $100 \mathrm{~g}$ ) \\
\hline Kadar air (\%) & Maksimum 5 & 2,68 \\
\hline Kadar Aw & $\mathrm{n} / \mathrm{a}$ & 0,50 \\
\hline Energi (kcal) & Minimum 450 & 565,9 \\
\hline Protein (g) & Minimum 10 & 14,09 \\
\hline Lipid (g) & Minimum 20 & 24,33 \\
\hline Karbohidrat & & 72,62 \\
\hline Sukrosa (g) & Maksimum 20 & $\mathrm{n} / \mathrm{a}$ \\
\hline Serat (g) & Minimum 5 & $\mathrm{n} / \mathrm{a}$ \\
\hline
\end{tabular}

a) Syarat mutu PMT Ibu Hamil menurut PMK No. 51 Tahun 2016 tentang Standar Produk Suplementasi Gizi

Cookies ikan gabus merupakan makanan suplementasi untuk ibu hamil yang dikembangkan dengan menggunakan substitusi tepung ikan gabus. Sebelum diberikan kepada subjek, produk cookies ikan gabus dan cookies standar telah terlebih dahulu diuji proksimat untuk mengetahui kandungan zat gizinya.

Berdasarkan hasil uji proksimat (Tabel 3), diketahui kadar air, energi, protein, lemak, dan juga karbohidrat (by different). Kadar air cookies ikan gabus cukup rendah $(2,68 \%)$ dan masih dibawah kadar air maksimum yang dipersyaratkan untuk oleh Kementerian Kesehatan RI sesuai dengan PMK No. 51 Tahun 2016. Kadar air pada cookies ikan gabus 
maupun cookies standar telah memenuhi syarat mutu yaitu kurang dari 5\%. Energi pada kedua cookies juga memenuhi standar yang ditentukan yaitu 565,9 kcal untuk cookies ikan gabus dan 529,5 kcal untuk cookies standar. Kandungan protein dan lemak cookies ikan gabus telah memenuhi persyaratan yaitu 14,09 g dan 24,33 g. Untuk kandungan karbohidrat, masing-masing adalah 72,62 g dan 73,28 g untuk cookies ikan gabus dan cookies standar. Secara keseluruhan, cookies ikan gabus telah memenuhi persyaratan kandungan zat gizi makro sesuai dengan PMK No. 51 Tahun 2016.

\section{Analisis Cemaran Mikrobiologi}

Tabel 4. Hasil Analisis Uji Mikrobiologi Cookies Ikan Gabus

\begin{tabular}{llc}
\multicolumn{1}{c}{$\begin{array}{c}\text { Cemaran } \\
\text { Mikrobiologi }\end{array}$} & \multicolumn{1}{c}{$\begin{array}{c}\text { Syarat Cemaran } \\
\text { Mikroba PMT lbu } \\
\text { Hamil }\end{array}$} & $\begin{array}{c}\text { Cookies } \\
\text { Ikan } \\
\text { Gabus }\end{array}$ \\
$\begin{array}{l}\text { TPC }^{\text {b }} \text { Bakteri (cfu/g) } \\
\begin{array}{l}\text { TPC Kapang/yeast } \\
\text { (cfu/g) }\end{array}\end{array}$ & $\begin{array}{c}\text { Maks. } 5 \times 10^{4} \\
2,9 \times 10^{2}\end{array}$ \\
TPC Jamur (cfu/g) $5 \times 10^{4}$ & $3,4 \times 10^{1}$ \\
E. coli & Maks. $5 \times 10^{4}$ & 0 \\
Salmonella & Negatif (dalam 1 g) & 0 \\
$\begin{array}{l}\text { Staphilococcus aureus } \\
\text { (cfu/g) }\end{array}$ & Negatif (dalam 25 g) & Negatif \\
\hline
\end{tabular}

a) Syarat cemaran mikroba PMT ibu hamil berdasarkan Keputusan Menteri Kesehatan No. 899/Menkes/SK/X/2009

Sesuai dengan Peraturan Menteri Kesehatan No. 51 Tahun 2016 tentang Standar Produk Suplementasi Gizi bahwa setiap makanan suplementasi yang diberikan kepada ibu hamil harus memenuhi batas cemaran mikroba, logam berat, dan cemaran lainnya sesuai dengan yang diatur oleh perundangundangan. Perbandingan cemaran mikroba cookies ikan gabus dan cookies standar dengan syarat cemaran mikroba PMT menurut Keputusan Menteri Kesehatan No. 899/Menkes/SK/X/2009 ditampilkan pada Tabel 4.

Faktor-faktor yang menyebabkan meningkatnya aktivitas mikroba, diantaranya: nutrient, aktivitas air (activity water/Aw), waktu, suhu, nilai dan $\mathrm{pH}^{24}$ Nutrien yang terdapat dalam cookies merupakan media pertumbuhan yang baik bagi mikroorganisme, disamping itu meningkatnya kadar air pada cookies juga mampu meningkatkan aktivitas mikroorganisme bakteri pada cookies, akan tetapi proses pemangganggan cookies dengan suhu yang tepat mampu membunuh mikroorganisme bakteri yang tumbuh pada cookies. ${ }^{25}$

Selain karena bakteri, kerusakan cookies lainnya juga dikarenakan kapang. Pada proses pemanggangan sejumlah mikroorganisme pada cookies banyak yang berkurang, akan tetapi spora mikroorganisme masih hidup, kapang melakukan proses kontaminasi, melalui udara yang masuk pada saat proses pendinginan, sebelum proses pengemasan, sehingga waktu yang dibutuhkan antara proses pengemasan dan pendinginan, tidak terlalu lama dengan kondisi ruangan yang bersih dan steril. 25

Salah satu cemaran pada ikan adalah E. coli, Salmonella dan staphylococcus aureus. ${ }^{26}$ Pada cookies ikan gabus, proses pengolahan tepung ikan gabus dilakukan dengan proses perebusan pada suhu tinggi, suhu yang tinggi mengakibatkan turunnya jumlah mikroba yang ada pada bahan tersebut. $^{27}$

Kedua cookies yang diberikan kepada ibu hamil dalam penelitian ini telah melalui uji laboratorium untuk memastikan bahwa tidak ada cemaran mikrobiologi dalam kedua cookies tersebut sehingga terjamin keamanan pangannya. Setelah melalui uji mikrobiologi, kedua cookies yang diberikan, baik cookies ikan gabus maupun cookies standar, dinyatakan memenuhi batasan cemaran mikroba sehingga aman untuk dikonsumsi (Tabel 4).

\section{KESIMPULAN DAN SARAN}

Cookies ikan gabus dengan formula 60\% dapat diterima dengan cukup baik oleh ibu hamil. Cookies ikan gabus memiliki kandungan gizi (energi, protein, lemak, dan karbohidrat) dan kadar air yang telah memenuhi persyaratan mutu PMT ibu hamil sesuai dengan Standar Produk Suplementasi Gizi. Cookies ikan gabus juga aman untuk dikonsumsi karena telah memenuhi syarat cemaran mikroba pada PMT ibu hamil.

\section{SARAN}

Karena daya terima ibu hamil yang belum maksimal terhadap produk cookies ikan gabus ini (skala 3,63 
dari 5), diperlukan adanya pengembangan formula cookies yang lebih baik lagi untuk menghilangkan sifat-sifat organoleptic yang kurang disukai ibu hamil (seperti: aftertaste, aroma amis, tekstur, dan lainnya), sehingga cookies lebih dapat diterima oleh ibu hamil.

\section{DAFTAR PUSTAKA}

1. WHO. 2016. WHO recommendation on nutrition education on energy and protein intake during pregnancy. Diakses pada tanggal 29 Januari 2019 melalui https://extranet.who.int/rhl/ topics/preconception-pregnancy-childbirthand-postpartum-care/antenatal-care/whorecommendation-nutrition-education-energy-andprotein-intake-during-pregnancy

2. Pena, M \& Bacalao, J. 2002. Malnutrition and Poverty. Ann Rev Nutr. Vol. 22, pp. 241-253, https:// doi.org/10.1146/annurev.nutr.22.120701.141104

3. Amosu, A.M. \& Degun, A. M. 2014. Impact of Maternal Nutrition on Birth Weight of Babies. Biomedical Research, Vol. 25, No. 1, pp. 75-78, https://www.biomedres.info/biomedical-research/ impact-of-maternal-nutrition-on-birth-weight-ofbabies.html

4. Kemenkes RI. 2013. Riset Kesehatan Dasar; RISKESDAS 2013. Jakarta: Balitbang Kementerian Kesehatan Republik Indonesia

5. Rao S, Kanade AN, Yajnik CS, et al. 2009. Seasonality in maternal intake and activity influence offspring's birth size among rural Indian mothers-Pune Maternal Nutrition Study. Int J Epidemiol. Vol. 38, No. 4, pp. 1094-1103. https://dx.doi. org/10.1093\%2Fije\%2Fdyp223

6. Kemenkes RI. 2018a. Petunjuk Teknis Pemberian Makanan Tambahan (Balita - Anak Sekolah - Ibu Hamil). Jakarta: Kementerian Kesehatan Republik Indonesia

7. Harianti. 2011. Ikan Gabus dan Berbagai Manfaat Albumin. Jurnal Balik Diwa. Vol. 2, No. 1, http:// stitek-balikdiwa.ac.id/images/jbd_v2n1_3.pdf

8. Kemenkes RI. 2018b. Tabel Komposisi Pangan Indonesia 2017. Jakarta: Kementerian Kesehatan Republik Indonesia

9. Prastari C, Yasni S, \& Nurilmala M. 2017. Karakteristik Protein Ikan Gabus yang Berpotensi sebagai Antihiperglikemik. JPHPI, Vol. 20, No. 2, pp. 414-423, https://jurnal.ipb.ac.id/index.php/jphpi/article/ view/18109/12945

10. Kementerian Kelautan dan Perikanan Indonesia. 2011. Statistik Perikanan Tangkap Indonesia 2010. Jakarta: Direktorat Jenderal Perikanan Tangkap
11. Arfiyanti. 2013. Cookies Ikan Gabus Sebagai Makanan Tambahan Untuk Ibu Hamil Trimester II. Prosiding Semirata FMIPA Universitas Lampung, https://jurnal. fmipa.unila.ac.id/semirata/article/viewFile/567/797

12. Stone, H dan Sidel. J. L. 2004. Sensory Evaluation Practices Third Edition. California, USA: Elsevier Academic Press

13. Winarno FG. 2008. Kimia Pangan dan Gizi. Jakarta (ID): PT Gramedia Pustaka Utama.

14. Fiani, M., \& Japarianto, E. 2012. Analisa pengaruh food quality dan brand image terhadap keputusan pembelian roti kecil toko roti Ganepis di Kota Solo. Jurnal Manajemen Pemasaran, Vol. 1, No. 1, pp. 1-6. https://media.neliti.com/media/ publications/134151-ID-analisa-pengaruh-foodquality-dan-brand.pdf

15. Winarno FG. 1990. Tempe, Misteri Gizi dari Jawa, Info Pangan. Teknologi Pangan dan Gizi, Fatameta, IPB, Bogor.

16. Puspitarini, T., Pratjojo, W., \& Kusumastuti, E. 2014. Efektivitas Penggunaan Kulit Jeruk Nipis Sebagai Penghilang Bau Amis Pada Ikan. Indo J Chem Sci, Vol. 3, No. 2, hlm 113-118. https://journal.unnes.ac.id/ sju/index.php/ijcs/article/view/3496

17. Smith. W. H. 1972. Biscuit, Crackers and Cookies Technology Production and Management. London: Aplied Science Publisher, LTD.

18. Sari, D. K., Agustiana, \& Puspitasari, F. 2019. Organoleptik Characteristic of Functional Biscuit enriched with Protein and Betacaroten. Tropical Wetland Journal, Vol. 5, No. 1, hlm 05-10. https:// doi.org/10.20527/twj.v5i1.68

19. Kurniadi, M., Angwar, M., Miftahkussolikhah, Affandi D. R., \& Khusnia, N. 2019. Karakteristik Cookies dari Campuran Tepung Ubi Kayu Termofikasi (Mocaf), Tempe, Telur, Kacang Hijau, dan Ikan Lele. Jurnal Dinamika Penelitian Industri, Vol. 30, No. 1. http:// dx.doi.org/10.28959/jdpi.v30i1.4096

20. Sari, D, K., Marliyati, S. A., Kustiyah, L., Khomsan, A., \& Gantohe, T. M. 2014. Uji Organoleptik Formulasi Biskuit Fungsional Berbasis Tepung Ikan Gabus (Ophiocephalus striatus). Agritech, Vol 34, No. 2. https://doi.org/10.22146/agritech.9501

21. Fitri, N. \& Purwani, E. 2017. Pengaruh Substitusi Tepung Ikan Kembung (Rastrelliger brachysoma) terhadap Kadar Protein dan Daya Terima Biskuit. Prosiding Seminar Nasional Gizi 2017, Program Studi IImu Gizi UMS "Strategi Optimasi Tumbuh Kembang Anak". https://publikasiilmiah.ums.ac.id/ bitstream/handle/11617/8692/Prosiding_SemnasGIZI-2017_15.pdf?sequence $=1$ \&isAllowed $=\mathrm{y}$

22. Winarno, F. G. 1997. Kimia Pangan. Pusat Pengembangan Teknologi Pangan. Institute Pertanian Bogor 
23. Pradimurti. 2007. Pengaruh Pengolahan Terhadap Nilai Gizi Pangan. Bogor. Institut Pertanian Bogor

24. Suardana, I. W. \& Swacita, I. B. N. 2009. Higiene Makanan. Denpasar: Udayana University Press

25. Fardiaz, S. \& Laksmi, B. S. 1989. Mikrobiologi Pangan II. Bogor: Laboratorium Mikrobiologi Pangan IPB

26. Badan Standarisasi Nasional. 2009. Standar Nasional Indonesia: Batas Maksimum Cemaran Mikroba dalam Pangan (SNI 7388:2009). https://pspk. fkunissula.ac.id/sites/default/files/2017_kpdl_SNI7388-2009-Batas-maksimum-cemaran-mikrobadalam-pangan.pdf
27. Mailia, R., Yudhistira, B., Pranoto, Y., Rochdyanto, S., Rahayu, E. S. 2015. etahanan Panas Cemaran Escherichia coli, Staphylococcus aureus, Bacillus cereus dan Bakteri Pembentuk Spora yang Diisolasi dari Proses Pembuatan Tahu di Sudagaran Yogyakarta. Agritech, Vol. 35, No. 3. https://doi. org/10.22146/agritech.9341 